Barn Swallow (39); Purple Martin (13); Black-billed Magpie (21); Black-capped Chickadee (6); Common Crow (91); House Wren (2); Brown Thrasher (1); Rabin (43); Swainson's Thrush (179); Grey-cheeked Thrush (23); Veery (1); Ruby-crowned Kinglet (1); Sprague's Pipit (2); Loggerhead Shrike (7); Starling (57); Philadel phisa Vireo (3); Blackand-White Warbler (2); Orange-crowned Warbler (38); Yellow Wiarbler (51); Magnolia Warbler (1); Myrtle Wanbler (135); Blackpoll Warbler (9); Palm Warbler (9); Ovenbird (1); Northern Waterthrush (33); Yellowthroat (6); House Sparrow (520); Western Meadowlark (128); Yellow-headed Blackbind (222); Redwinged Blackbird (497); Baltimore Oriole (6); Rusty Blackbird (13);
Brewer's Blackbind (119); Common Grackle (85); Brown-headed Cowbird (48); Rosebreasted Grosbeak (1); Purple Finch (8); Pine Siskin (1); Rufous-sided Towhee (10); Savannah Sparrow (89); Baird's Sparrow (11); Vesper Sparrow (36); Lark Sparrow (2); Slate-colored Junoo (5); Oregon Junco (1); Tree Sparrow (6); Chipping Sparrow (43); Clay-colored Sparrow (188); Harris's Sparrow (217); White-orowned Sparrow (265); Whitethreated Sparrow (454); Fox Sparrow (6); Linceln's Sparrow (328); Song Sparrow (45); McCown's Longspur (5); Laapland Longspur (475); Chestnut-collared Longspur (63); Snow Bunting (20). Compiler: FRANK BRAZIER, Regina.

\title{
A MANITOBA RECORD OF THE CATTLE EGRET
}

\section{by David Plews, Brandon}

On May 27 of this year (1961), Mr. Lane and I were down at the Big Marsh that extends from Alexander to Griswold, known by some as "Ashbury Marsh." Our trip was mainly to search for nests of American Avocets.

As we were motoring by an arm of the marsh, we spotted a fairly tall white bird, standing in the high grass beside the water. It was a startling sight, because as you know, we have no local birds with this appearance.

We both gave the stranger a long scrutiny through our glasses, then dug into our Peterson's for guidance. Nothing seemed to quite fit this particular bird, as is was evidently too short to be an American Egret and too slim to be a Snowy Egret. We gave some thought to it being an albino Black-crowned Heron, as it had about the same silhouette. However, this bird was not all white, having light brown patches on the pate, lower neck and lower back.
A few days later $\mathrm{Mr}$. and Mrs. Cleveland Grant arrived to spend the summer in bird photography. $\mathrm{Mr}$. Grant is well-known in that field, and is also a lecturer for the Audubon Society. We described the strange bird to both the Grants and also to Dr. Bill Gunn, the bird-song recorder for Toronto. Fortunately, the Grants saw the bird soon after, and at once said it was a Cattle Egret. Dr. Gunn had a copy of Peterson's Birds of Texas and sure enough, there was a coloured picture of the very bird!

About a week later we were back at the marsh again with a group of junior birders and some of the group saw the white bird again. Now, it is no longer at that spot in the marsh, but has probably moved to a more remote seotion where there may not be so many inquisitive bird-watchers!

Ed. Note-This is believed to be only the second Canadian record.

\section{PARTIAL ALBINO SANDHILL CRANE}

\section{by Richard S. Miller, University of Saskatchewan, Saskatoon}

On Thursday, April 27, I visited Last Mountain Lake with Doug Stephen. At the Leland Greenfield farm 4 miles west and 2 miles south of Hatfield I observed a partial albino Sandhill Crane. This bird was feeding with a flock of about 200 other Sandhills. From its size it appeared to be a first year bird.

The head, neck, breast and anterior portion of the back of the bird were pure white. This made the red on the head very noticeable. The posterior portion of the back and wings were the typical gray of a Sandhill Crane, although there was some mottling in the areas where the white blended into the gray.

I watched the bird from about 200 to 250 or 300 yards for about $20 \mathrm{~min}$ utes with 8-power binoculars. There was no question of the coloration as the bird was seen at every angle in good light, and it was unquestionably a Sandhill by its size and appearance. 